\title{
Energy efficiency index by considering number of occupants: a study on the lecture rooms in a university building
}

\author{
Noor Ameera Zakaria ${ }^{1}$, Mohammad Yusri Hassan ${ }^{2}$, Hayati Abdullah ${ }^{3}$, Md Pauzi Abdullah ${ }^{4}$, \\ Faridah Hussin $^{5}$, Siti Maherah Hussin ${ }^{6}$, Nur Najihah Abu Bakar ${ }^{7}$ \\ 1,2,3,4,5,6 Centre of Electrical Energy Systems, Institute of Future Energy, School of Electrical Engineering, \\ Faculty of Engineering, Universiti Teknologi Malaysia, Malaysia \\ ${ }^{7}$ School of Electrical Systems Engineering, Universiti Malaysia Perlis, Malaysia
}

\begin{tabular}{|c|c|}
\hline Article Info & ABSTRACT \\
\hline Article history: & The building sector is attributed to approximately $40 \%$ of the nation's energy \\
\hline Received Sep 21, 2018 & consumption and this accounts for a significant percentage of the nation's \\
\hline Revised Feb 10, 2019 & become an important subject in the national energy scenario. Energy \\
\hline Accepted Mar 22, 2019 & $\begin{array}{l}\text { Efficiency Index (EEI) is one of the energy consumption indicators that is } \\
\text { widely used in the building sector for measuring energy performance. }\end{array}$ \\
\hline Keywords: & $\begin{array}{l}\text { This index is generally measured based on the energy used per unit of } \\
\text { building floor area. However, this index is not able to directly identify other }\end{array}$ \\
\hline Commercial buildings & factors affecting energy usage. This paper suggests an Energy Efficiency \\
\hline Energy efficiency index & $\begin{array}{l}\text { Index (EEI) for determining the performance of lecturer rooms in a } \\
\text { university building. Unlike the conventional EEI the proposed EEI }\end{array}$ \\
\hline Lecture rooms & determines the room's energy usage performance by considering the number \\
\hline Number of occupants & of occupants. The study was conducted at the Faculty of Electrical \\
\hline University building & $\begin{array}{l}\text { Engineering, Universiti Teknologi Malaysia (UTM) and the results show that } \\
\text { the number of occupants significantly influences the energy usage } \\
\text { performance of rooms in a university building. }\end{array}$ \\
\hline
\end{tabular}

Copyright $@ 2019$ Institute of Advanced Engineering and Science. All rights reserved.

\section{Corresponding Author:}

Mohammad Yusri Hassan,

Centre of Electrical Energy Systems, Institute of Future Energy,

School of Electrical Engineering, Faculty of Engineering,

Universiti Teknologi Malaysia,

81310 UTM Johor Bahru, Johor, Malaysia.

Email: yusrih@utm.my

\section{INTRODUCTION}

Energy consumption in the commercial building sector has been gradually increasing and this affects the increase in energy production and utility bills. Based on Malaysia's Energy Statistics in 2016, approximatly $40 \%$ of the nation's energy is consumed by the building sector [1]. With such statistics on energy consumption and the fact that underdeveloped and developing countries mostly use fossil fuels as the main sources of energy, there is an urgent need to be energy efficient [2].

Commercial buildings include office buildings, shopping centres, storehouses, public administration and other commercial structures [3]. According to the Building Book Data; Council of Australian Governments, shopping mall and office buildings are the most energy demanding in many countries. In Australia, $60 \%$ of the energy consumed in commercial buildings are by the offices and shopping outlets [4].

Since university buildings are also high consumers of energy in the category of commercial buildings, many public universities in Malaysia have promoted energy management programs for better use of energy [5]. In order to promote a more sustainable way of consuming energy, energy management plays a significant role in achieving such a target. One of the public universities that implements the energy saving program is Universiti Teknologi Malaysia due to its high energy consumption and electricity bill. 
The increase in the number of students as well as the number of buildings has contributed to the high energy consumption and electricity bill. In 2010, energy consumption of the university was found to decrease significantly due to the implementation of the energy saving program.

This paper proposes a new Energy Efficiency Index (EEI) to track the energy consumption performance of a university building. Unlike the conventional EEI, the proposed EEI considers the number of occupants in a building which would reflect the actual performance of the building's energy consumption. A study was carried out at the Faculty of Electrical Engineering, Universiti Teknologi Malaysia (UTM) where the results and methodologies are presented in the following sections.

\section{ENERGY MANAGEMENT IN BUILDINGS}

\subsection{Retrofitting Equipment}

Renovation, retrofit and refurbishment of existing buildings are among the initiatives utilized to improve energy consumption performance in commercial buildings. Retrofitting can result in improved energy consumption and reduced energy demand [6]. This gives an opportunity to attract tenants as a result of the reduction in operational cost from energy efficiency retrofitting initiatives [3]. In addition, retrofitting could also affect the behavior of occupants concerning conserving energy. Williams et al. reported that the average energy savings that can be attributed to daylight harvesting as measured is approximately $28 \%$. However, the savings is affected by other factors including window size, space geometry, building location, time of year, and interior finishing and geometry [7].

Retrofits can also involve electrical and mechanical appliances such as replacing lightings and airconditioners with more energy efficient units. Erhan E. Dikel et al. reported that retrofitting lighting system with LEDs paired with sensors offer 79\% energy savings [8].

\subsection{Control System}

A building management system (BMS), is a computer-based control system installed in buildings that control and monitor the building' mechanical and electrical equipment which consists of softwares and hardwares. Adopting the Building Automation System (BAS) for real-time monitoring and control of the building services systems has become a top trend in the building sector [9]. As reported by Waide et al., approximately $22 \%$ of the energy consumed during building operations can be saved through the use of advanced building automation technologies. The advantages of BMS systems are the possibility of individual room control, increased staff productivity and saving time and money during maintenance [10, 11]. It can also be useful for reducing energy consumption. Saeed Kamali reported that BMS allows users to control each of the sub-systems individually and it also allows integrated control. He also reported that the cost of implementation of BMS for a building is about USD40,000 and can on the average reduce 50\% of energy consumption [9].

\subsection{Human Behavior}

Global climate change can affect many aspects in society including health, economic prospects, and food supply and water resources. Global climate change and environmental degradation are mainly caused by human behavior and can be improved through awareness and sustainable practice [12-14]. David Uzzell from the British Psychological Society, reported that energy efficiency programs, energy saving campaigns and information-based behavioral strategies rely more on the social, psychological and political dynamics that drive people's decision-making process to reduce energy usage than technology or standards [13]. The Behavioral Insights Team (BIT) [15] published a number of reports on the psychology of people's decisions when it comes to energy saving as shown in Figure1.

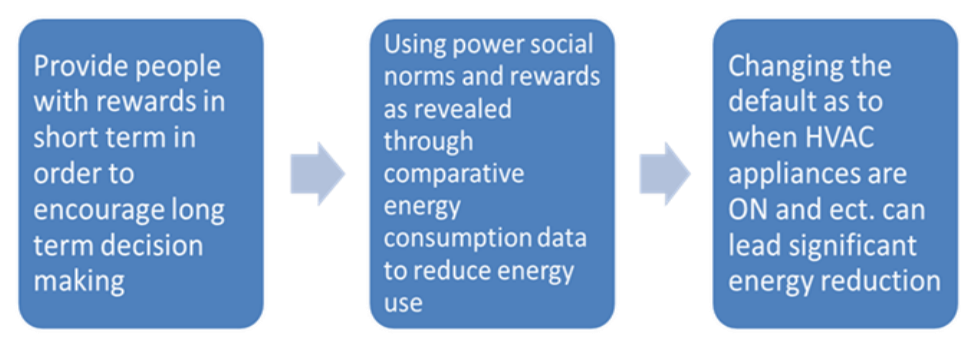

Figure 1. The psychology of people's decision [15] 


\section{ENERGY EFICIENCY INDEX}

Energy Efficiency Index (EEI) is an indicator to record the performance of a building and act as a point of reference which provides the baseline for energy consumption of a building. The EEI is also known as the Building Energy Index (BEI) [16], Energy Performance index (EPI) [17], and Energy Cost Index [18].

EEI acts as a standard baseline or limitation that organization should follow for energy index monitoring. The EEI for commercial buildings in Malaysia according to the Malaysian Standard (MS1525:2007) is $135 \mathrm{kWh} / \mathrm{m}^{2} /$ year [19]. The concept of EEI is often used because it represents a global index for energy efficiency in buildings. It also provides the owners, organization, technical personnel of buildings with an understanding of the performance of energy consumption in their buildings. In general, the equation for EEI is given as the ratio of the energy input to the factor related to the energy using component [20].

$$
E E I=\frac{\text { Energy input }}{\text { Factor related to the energy }}
$$

There are several factors related to the energy using component that could be considered such as [21]:

a) Weight of product produced

b) Number of items produced (industrial)

c) Weight of raw material used

d) Period of production

e) Period of plant usage

f) Number of beds (hospital)

g) Number of occupied rooms (hotel)

h) Number of occupants (lecture room)

Many researchers study EEI as a building index that incorporates tracking of performance of energy consumption in buildings which controls the usage of energy without exceeding the proposed baseline [19, 21-24]. S. Moghimi et al. [19] reported that most organizations implement EEI analysis for buildings using $\mathrm{kWh} / \mathrm{m}^{2}$, where energy consumption is based on the parameter of per unit floor area.

\subsection{Proposed EEI Model for Lecture Room}

A study for a university building was conducted where the EEI [20] was determined from the total energy consumption, $\mathrm{kWh}$ per gross floor area, $\mathrm{m}^{2}$ as shown in (2).

$$
E E I=\frac{E C}{A}
$$

EC is the total energy consumption of a building expressed in kWh and A is the gross floor area, in $\mathrm{m}^{2}$. However, the EEI in (2) does not directly identify the effect of the occupants because it does not include the occupant density of the building in the equation. Most university buildings are designed based on the number of occupants. However, the number of students in a lecture room changes randomly and might not meet the expected capacity of the room.

In this study, the proposed EEI model for a lecture room is based on three parameters consisting of the total energy consumption, number of occupants and gross floor area as shown in (3).

$$
E E I_{p}=\frac{E C}{A} \bullet \frac{O_{\text {base }}}{O_{\text {actual }}}
$$

Where the energy consumption (EC) is in $\mathrm{kWh}$; gross floor area (A) is in $\mathrm{m}^{2}$; $\mathrm{O}_{\text {base }}$ is the base number of occupants, and $\mathrm{O}_{\text {actual }}$ is the actual number of occupants. The unit of the proposed EEI is expressed in $\mathrm{kWh} / \mathrm{m}^{2}$.

\section{CASE STUDY}

This case study was conducted in a selected building in the Faculty of Electrical Engineering (FKE), UTM. FKE is one of the sixteen (16) faculties on campus and has the highest energy consumption among the other faculties. FKE has 13 blocks which consists of lecture rooms, offices and laboratories. The electricity 
use in the buildings are mainly for lighting, air-conditioning and appliances such as computers and other appliances. Normal working days are from Sunday to Thursday.

The obtained data were analyzed based on the work conducted in lecture rooms at the P16 building. Several parameters were considered in the analysis, such as load usage, space area, operation hours and occupant capacity. The lecture rooms are mainly used during the semester period. Six lecture rooms in the P16 building were selected for this case study using the criteria of occupant density, gross floor area and energy consumption.

Table 1 presents the P16 building details of lecture room. The load analysis for each room showed that the highest power consumption of $11.19 \mathrm{~kW}$ was for air- conditioning. Each room was installed with 3 (three) split air-conditioning units with a total of $15 \mathrm{hp}$ capacity. Besides air-conditioning, lighting is also a major energy consumer. The average power consumption in each room in the P16 building was determined to be $13.203 \mathrm{~kW}$.

Table 2 shows the lecture rooms schedule showed that the rooms are frequently used on Wednesday. The usage time for the rooms was assumed to be 7 hours [25]. Each lecture room was designed to accommodate 120 people. However, the number of occupants is normally less than the design value.

Table 1. P16 Building Details

\begin{tabular}{cccc}
\hline Room & Function & Gross Floor Area $\left(\mathrm{m}^{2}\right)$ & Room Capacity (Person) \\
\hline Demo 1 & Lecture room & 204.35 & 120 \\
Demo 2 & Lecture room & 204.35 & 120 \\
BKT 1 & Lecture room & 204.35 & 120 \\
BKT 2 & Lecture room & 204.35 & 120 \\
BKT 3 & Lecture room & 204.35 & 120 \\
BKT 4 & Lecture room & 204.35 & 120 \\
\hline
\end{tabular}

Table 2. Students Occupancy during Lecture Hour on Wednesday [25]

\begin{tabular}{|c|c|c|c|c|c|c|c|c|c|c|c|}
\hline Time/Day & $\begin{array}{c}0800- \\
0900\end{array}$ & $\begin{array}{c}0900- \\
1000\end{array}$ & $\begin{array}{l}1000- \\
1100\end{array}$ & $\begin{array}{l}1100- \\
1200\end{array}$ & $\begin{array}{l}1200- \\
1300\end{array}$ & $\begin{array}{r}1300- \\
1400\end{array}$ & $\begin{array}{r}1400- \\
1500\end{array}$ & $\begin{array}{l}1500- \\
1600\end{array}$ & $\begin{array}{c}1600- \\
1700\end{array}$ & $\begin{array}{l}1700- \\
1800\end{array}$ & $\begin{array}{r}1800- \\
1900\end{array}$ \\
\hline BKT 1 & 15 & 80 & 80 & 25 & 25 & & & & & 32 & 32 \\
\hline BKT 2 & 31 & 31 & 52 & 30 & 30 & & & & & & \\
\hline BKT 3 & 27 & 27 & & 28 & 28 & & & & & & \\
\hline BKT 4 & 41 & 41 & & & & & & & & & \\
\hline DEMO 1 & & 11 & 11 & 59 & 58 & & & & & & \\
\hline DEMO 2 & 23 & 29 & 29 & & 33 & & & & & & \\
\hline
\end{tabular}

\section{RESULTS AND ANALYSIS}

The data from the lecture rooms in the P16 building were used to evaluate the proposed EEI in terms of energy consumption, gross floor area and number of occupants. An observation of a lecture room for two different scenarios in which the number of occupants is different. In this case, the design number of occupants for each lecture room is 120 people. However, it can be seen that the actual number of people is much lesser than the design value during most of the lecture sessions. In the worst case scenario, there were less than 20 people in the lecture room which could lead to energy wastage.

The conventional EEI is unable to directly identify the effect of occupant density in the building because it considers the energy consumption and gross floor area only. The resulting EEI does not include other factors in the calculation but every lecture room in university buildings are mostly design based on the number of occupants. Reduction in the number of occupants can lead to inefficient use of electricity.

Figure 2 shows the result of the proposed EEI for six lecture rooms evaluated on a Wednesday. It can be seen that the highest EEI is $0.7047 \mathrm{kWh} / \mathrm{m}^{2}$, during lecture session held in DEMO 1 at 9 am to 11 am due to the low occupancy in the room.

Figure 3 shows the comparison between the conventional EEI and the proposed EEI for a period of one week. The data were analyzed based on the number of highest occupants in the lecture room. It can be seen that the conventional EEI (blue bar) remains constant regardless of the number of occupants. Meanwhile, the proposed EEI (red bar) successfully shows the effectiveness of the additional factor of occupants in indicating the energy wastage in each room. The figure shows that the BKT 2 room has the highest EEI of $0.1463 \mathrm{kWh} / \mathrm{m}^{2}$ compared to other rooms. It can be concluded that higher value of EEIs demonstrates opportunity for improvement in terms of energy savings. Lower EEI indicates better performance in terms of energy consumption especially when the EEI is less than $0.0646 \mathrm{kWh} / \mathrm{m}^{2}$. 


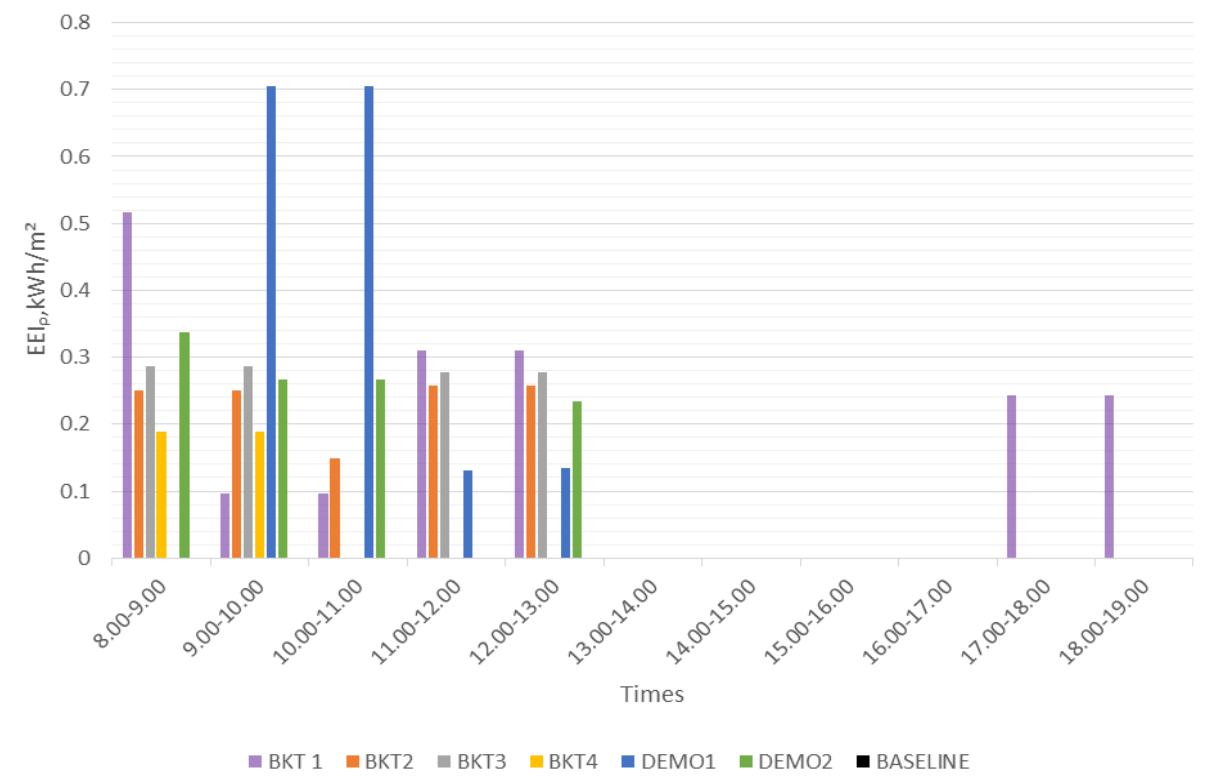

Figure 2. Results using proposed EEI on wednesday

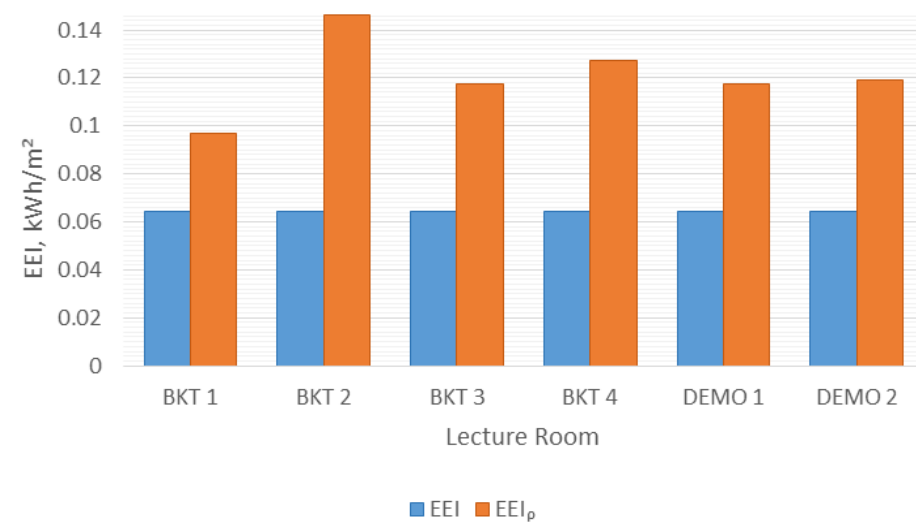

Figure 3. Comparison between conventional EEI and proposed EEI

The proposed EEI definition has shown that including the number of occupants in determining a building's EEI will represent a clearer picture of energy wastage in evaluating a building's energy performance. Apart from occupancy factor, other factors may also contribute to energy consumption such as the use of electrical devices, air-conditioning and lighting. With the inclusion of the occupancy factor in the calculation of the EEI, the energy consumption in a lecture room can be represented to indicate how the occupant density in a building space affects the energy usage.

\section{CONCLUSION}

This paper has presented a study for lecture rooms in a faculty building in UTM. The approach used in determining the Energy Efficiency Index (EEI) includes the effect of occupant density in a room. It can be seen that occupant density is a significant factor in determining EEI for lecture rooms in university buildings. Thus, the proposed calculation for EEI is expected to be a useful tool in evaluating university buildings' energy performance towards achieving energy efficiency. 


\section{ACKNOWLEDGEMENTS}

This work was supported by the Ministry of Higher Education (MOHE), Malaysia and Universiti Teknologi Malaysia (UTM) through the Research University Grant (GUP) vot. 18 H30.

\section{REFERENCES}

[1] S. T. E. Commission), Malaysia Energy Statistics Handbook 2016. Putrajaya, Malaysia, 2016.

[2] J. Vujić, D. P. Antić, and Z. Vukmirović, "Environmental impact and cost analysis of coal versus nuclear power: The U.S. case," Energy, vol. 45, no. 1, pp. 31-42, 2012/09/01/ 2012.

[3] R. Ruparathna, K. Hewage, and R. Sadiq, "Improving the energy efficiency of the existing building stock: A critical review of commercial and institutional buildings," Renewable and Sustainable Energy Reviews, vol. 53, pp. 1032-1045, 2016/01/01/ 2016.

[4] D. o. t. E. a. Energy. (2018). Australian Energy Statistics 2017. Available: https://www.energy.gov.au/publications/australian-energy-update-2018

[5] H. M. Bakar NNA, Abdullah H, Rahman HA, Pauzi MD, Hussin F, "Sustainable energy management practices audits effect on EEI: A study on university buildings.," presented at the Proceedings of global engineering, science and technology conference, Dubai, 2013.

[6] Y. Pan, Z. Huang, and G. Wu, "Calibrated building energy simulation and its application in a high-rise commercial building in Shanghai," Energy and Buildings, vol. 39, no. 6, pp. 651-657, 2007/06/01/ 2007.

[7] A. Williams, B. Atkinson, K. Garbesi, E. Page, and F. Rubinstein, "Lighting controls in commercial buildings," Leukos, vol. 8, no. 3, pp. 161-180, 2012.

[8] E. E. Dikel, G. R. Newsham, H. Xue, and J. J. Valdés, "Potential energy savings from high-resolution sensor controls for LED lighting," Energy and Buildings, vol. 158, no. Supplement C, pp. 43-53, 2018/01/01/ 2018.

[9] S. Kamali, G. Khakzar, and S. Abdali HajiAbadi, Effect of Building Management System on Energy Saving. 2014, pp. 333.

[10] W. Li, T. Logenthiran, V.-T. Phan, and W. L. Woo, "Intelligent housing development building management system (hdbms) for optimized electricity bills," in Environment and Electrical Engineering and 2017 IEEE Industrial and Commercial Power Systems Europe (EEEIC/I\&CPS Europe), 2017 IEEE International Conference on, 2017, pp. 1-6: IEEE.

[11] P. Delgoshaei, M. Heidarinejad, K. Xu, J. R. Wentz, P. Delgoshaei, and J. Srebric, "Impacts of building operational schedules and occupants on the lighting energy consumption patterns of an office space," Building Simulation, journal article vol. 10, no. 4, pp. 447-458, August 012017.

[12] T. Dietz, G. T. Gardner, J. Gilligan, P. C. Stern, and M. P. Vandenbergh, "Household actions can provide a behavioral wedge to rapidly reduce US carbon emissions," Proceedings of the National Academy of Sciences of the United States of America, vol. 106, no. 44, pp. 18452-18456, 10/26 08/02/received 2009.

[13] T. Hong, S. C. Taylor-Lange, S. D’Oca, D. Yan, and S. P. Corgnati, "Advances in research and applications of energy-related occupant behavior in buildings," Energy and Buildings, vol. 116, pp. 694-702, 2016/03/15/ 2016.

[14] E. R. Frederiks, K. Stenner, E. V. Hobman, and M. Fischle, "Evaluating energy behavior change programs using randomized controlled trials: Best practice guidelines for policymakers," Energy Research \& Social Science, vol. 22, pp. 147-164, 2016/12/01/ 2016.

[15] B. I. T. Cabinet Office, "Behaviour change and energy use: behavioural insights team paper," p. 35, 2011.

[16] N. Madlool, "Building Energy Performance and the Influence of the Operational Parameters in an Educational Hospital," Journal of University of Babylon for Pure and Applied Sciences, vol. 26, no. 2, pp. 69-77, 2018.

[17] B. Chai, A. Costa, S. D. Ahipasaoglu, C. Yuen, and Z. Yang, "Optimal meeting scheduling in smart commercial building for energy cost reduction," IEEE Transactions on Smart Grid, 2016.

[18] C. E. Kontokosta, "A market-specific methodology for a commercial building energy performance index," The Journal of Real Estate Finance and Economics, vol. 51, no. 2, pp. 288-316, 2015.

[19] S. Moghimi, F. Azizpour, S. Mat, C. H. Lim, E. Salleh, and K. Sopian, "Building energy index and end-use energy analysis in large-scale hospitals - case study in Malaysia," Energy Efficiency, journal article vol. 7, no. 2, pp. 243-256, April 012014.

[20] H. M. Ahmad AS, Abdullah H, Rahman HA, Majid MS, Bandi M, "Energy efficiency measurements in a Malaysian public university," presented at the Proceedings of the IEEE international conference on power and energy (PECon), 2012.

[21] N. N. Abu Bakar et al., "Energy efficiency index as an indicator for measuring building energy performance: A review," Renewable and Sustainable Energy Reviews, vol. 44, no. Supplement C, pp. 1-11, 2015/04/01/ 2015.

[22] A. A. Jamaludin, N. Z. Mahmood, and Z. Ilham, "Performance of electricity usage at residential college buildings in the University of Malaya campus," Energy for Sustainable Development, vol. 40, no. Supplement C, pp. 85-102, 2017/10/01/ 2017.

[23] F. Khayatian, L. Sarto, and G. Dall'O, "Building energy retrofit index for policy making and decision support at regional and national scales," Applied Energy, vol. 206, no. Supplement C, pp. 1062-1075, 2017/11/15/ 2017.

[24] R. Rahardjati, M. F. Khamidi, and A. Idrus, "The level of importance of criteria and sub criteria in green building index malaysia," 2010.

[25] N. N. A. Bakar et al., "Identification building energy saving using Energy Efficiency Index approach," in 2014 IEEE International Conference on Power and Energy (PECon), 2014, pp. 366-370. 


\section{BIOGRAPHIES OF AUTHORS}
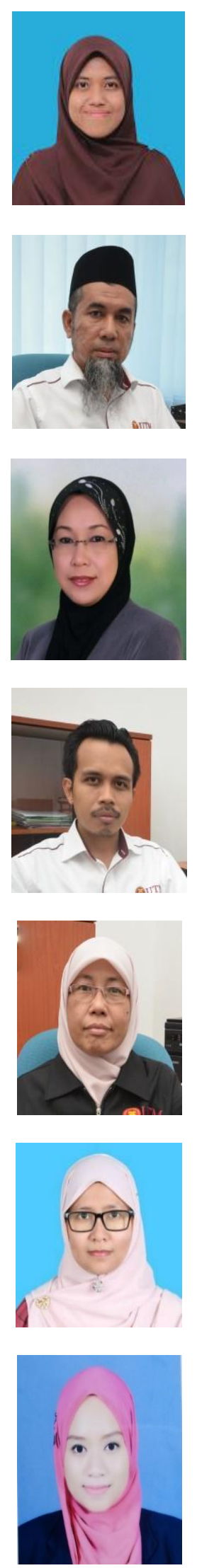

Noor Ameera Zakaria was born on 10 July 1994 in Kuala Lumpur. Currently, she is pursuing her MPhil in electrical engineering at School of Electrical Engineering, Faculty of Engineering, Universiti Teknologi Malaysia (UTM), Johor. She received her bachelor degree in engineering (Electrical-Power) in 2017 under the same university. Her current research involves energy efficiency and power management in buildings.

Mohammad Yusri Hassan received his $\mathrm{PhD}$ in Power System Economics from the University of Strathclyde, Glasgow, U.K. in 2004. He is a Certified Energy Manager under the ASEAN Energy Management Scheme (AEMAS). He is currently a Professor in the School of Electrical Engineering, Faculty of Engineering, Universiti Teknologi Malaysia (UTM), Johor, Malaysia and also the Director of the Centre of Electrical Energy Systems (CEES), UTM, Johor, Malaysia. His research interests include power system economics, deregulated electricity market, transmission pricing, energy efficiency and renewable energy.

Ir. Hayati Abdullah is an Associate Professor at the School of Mechanical Engineering, Faculty of Engineering Universiti Teknologi Malaysia (UTM) and currently holds the position as Director of the Centre for Teaching and Learning at the UTM Academic Leadership, UTMLead. Ir. Hayati specialises in Thermodynamics, more particularly in the area of Air-Conditioning and Energy Management. She was trained in Energy Management in Sweden and is a Certified Energy Manager. She is also a Registered Electrical Energy Manager with the Energy Commission Malaysia.

Dr. Md Pauzi bin Abdullah is an Associate Professor at School of Electrical Engineering, Faculty of Engineering, Universiti Teknologi Malaysia. He is also a Chartered Engineer registered in Engineering council, UK. He received the bachelor's degree (B.Eng) in Electrical \& Electronic Engineering from Universiti Tenaga Nasional (Uniten), Malaysia in 2002, master's degree (M.Sc) in Electrical Power Engineering and doctorate degree (Ph.D) in University of Strathclyde, Glasgow, United Kingdom in 2003 and 2008 respectively. His research interests include power systems analysis, power systems security, deregulated electricity market and demand side management.

Faridah Hussin is a Senior Lecturer at School of Electrical Engineering, Faculty of Engineering, Universiti Teknologi Malaysia. She received her B.Eng. in Electrical and Electronic Engineering from University of Strathclyde, United Kingdom in 1987 and M.Eng in Electrical Power Engineering from Universiti Teknologi Malaysia in 1990. Her research interests are Deregulated Electricity market and energy efficiency

Dr. Siti Maherah bt Hussin is a Senior Lecturer at School of Electrical Engineering, Faculty of Engineering, Universiti Teknologi Malaysia (UTM), Johor Bahru. She received her Bachelor of Electrical Engineering in 2009 with first class honours, Master of Engineering (Electrical-Power) in 2011 and PhD in Coordinated Generation and Transmission Maintenance Scheduling Using Mixed Integer Linear Programming from Universiti Teknologi Malaysia. Her research interest is in Generation Maintenance Scheduling.

Nur Najihah Abu Bakar was born on 5 September 1989 in the state of Kedah, is a lecturer at Universiti Malaysia Perlis (UNImap). She is graduate from Univertiti Teknologi Malaysia (UTM) under Electrical Engineering field. Her research interests includes renewable energy, energy management and power. Some related journal published by her are Microgrid and load shedding scheme during islanded mode: A review, Energy Efficiency Index As An Indicator for Measuring Building Energy Performance, Sustainable Energy Management Practices and Its Effect on EEI: A Study on University Buildings, Identification building energy saving using Energy Efficiency Index approach, Sustainable Energy Management Practices and Its Effect on EEI: A Study on University Buildings, and Study of Lightning Fatalities in Malaysia 2004-2012. 